\title{
ANALISIS INFORMATION TECHNOLOGY GOVERNANCE PADA PT. PERTAMINA (PERSERO)
}

\author{
S.Thya Safitri \\ Program Studi Teknik Informatika Sekolah Tinggi Teknologi Telematika Telkom, Purwokerto \\ sisil@stttelematikatelkom.c.id
}

\begin{abstract}
ABSTRAK
Information Technology Governance (IT Governance) merupakan faktor penting bagi organisasi atau perusahaan dalam memanfaatkan teknologi informasi. Adanya IT Governance akan memberikan jaminan bahwa pemanfaatan teknologi informasi dapat sejalan dengan tujuan organisasi. PT. Pertamina (Persero) sebagai perusahaan minyak berskala nasional yang telah berkomitmen untuk memberikan kontribusi yang terbaik bagi perekonomian Indonesia telah melakukan transformasi perusahaan menjadi dua tema besar, yaitu fundamental dan bisnis. Untuk mendukung komitmen tersebut, maka diperlukan peran IT yang besar. Pada Code of Corporate Governance PT.Pertamina, dicantumkan mengenai pentingnya penerapan IT Governance dalam mendukung proses bisnis yang dilakukan PT. Pertamina.
\end{abstract}

Keyword : IT Governance, PT. Pertamina, bisnis proses

\section{Pendahuluan}

Penerapan Teknologi Informasi (TI) pada suatu perusahaan memerlukan biaya yang cukup besar dengan kemungkinan resiko kegagalan yang cukup besar pula. Namun secara bersamaan, penerapan TI juga memberikan peluang atau kesempatan terjadinya transformasi dan produktifitas bisnis yang telah berjalan (Sakam,2005).

Adanya keterbatasan sumber daya (seperti data, sistem aplikasi, teknologi, fasilitas dan sumber daya manusia), serta adanya kebutuhan informasi yang berkualitas merupakan faktor utama mengapa pemanfaatan teknologi informasi perlu direncanakan secara sistematis. Karena itu diperlukan adanya panduan atau tata kelola yang mengatur bagaimana pemanfaatan teknologi informasi dalam organisasi. Panduan ini selanjutnya dikenal dengan istilah Information Technology Governance (Budiati,2006).

Tata kelola teknologi informasi pada proses pengelolaan data adalah manajemen pengelolaan data yang merupakan aset penting bagi perusahaan ataupun organisasi. Tata kelola teknologi informasi pada proses pengelolaan data yang kurang baik akan menimbulkan beberapa permasalahan yang akan menjadi kelemahan (vulnerabilities) sehingga akan menimbulkan ancaman (threats) seperti kejadian kehilangan, perusakan, pencurian dan penyadapan data penting pada suatu perusahaan atau organisasi (Hartanto,2008).

Sebagai bagian dari manajemen perubahan yang tengah digulirkan berkenaan dengan perubahan status hukum 
Pertamina menjadi Badan Usaha Milik

Negara (BUMN) Perseroan, PT Pertamina

(Persero) berkomitmen untuk melaksanakan

praktik-praktik Good Corporate

Governance (GCG) atau tata kelola

perusahaan yang baik sebagai bagian dari

usaha untuk pencapaian visi dan misi

perusahaan. Salah satu praktik GCG

tersebut adalah dengan melibatkan IT

dalam mendukung proses bisnis yang

dijalankan oleh PT. Pertamina. Maka, IT

yang dipandang sebagai salah satu hal

penting dalam perusahaan harus dikelola

dengan baik, melalui suatu mekanisme IT

Governance.

\section{Definisi IT-Governance}

IT Governance adalah bentuk suatu pertanggungjawaban para pimpinan puncak dan manajemen pelaksana, yang merupakan bagian yang terintegral dari pengaturan perusahaan, mencakup kepemimpinan dan struktur organisasi serta proses-proses yang menjamin untuk mendukung pengelolaan IT dan menindak lanjuti sasaran dan strategi organisasi (Weill,2004).

Lima hal pokok yang harus tercakup dalam IT Governance, yaitu:

a. Strategic alignment. Strategi IT harus selaras dengan strategi bisnis organisasi.

b. Value delivery. Penerapan IT harus memberikan kontribusi terhadap tingkat pencapaian tujuan organisasi. c. Risk management. Resiko-resiko terkait IT harus dapat dipetakan dan dampaknya dapat ditekan ke tingkat yang dapat diterima.

d. Resource management. Sumber daya IT yang diperlukan harus tersedia dan digunakan secara optimal.

e. Performance measurement. Performa layanan yang dihasilkan harus diukur dari setiap tahapan proses IT, untuk memastikan output yang dihasilkan sesuai dengan yang diharapkan (Mirbaha,2008).

IT Governance memiliki tanggung jawab, sebagai berikut (Suryani,2009):

a. Memastikan kepentingan stakeholder disertakan dalam penyusunan strategi organisasi.

b. Memberikan arahan pada proses implementasi strategi organisasi.

c. Memastikan proses-proses implementasi yang dilakukan menghasilkan output yang terukur.

d. Memastikan adanya informasi dari pengukuran output yang dihasilkan.

e. Memastikan output yang diperoleh telah selesai dengan yang diharapkan.

IT Governance merupakan suatu prosedur arahan untuk penerapan suatu pengaturan organisasi, untuk mendukung pengelolaan IT secara internal dan menindak lanjuti sasaran dan strategi organisasi. 
IT Governance dapat juga diartikan sebagai keputusan-keputusan yang diambil sehingga memastikan adanya alokasi penggunaan IT dalam strategi-strategi organisasi yang bersangkutan. IT Governance merefleksikan adanya penerapan prinsip-prinsip organisasi dengan memfokuskan pada kegiatan manajemen dan penggunaan TI untuk pencapaian organisasi. Dengan demikian, IT governance pada intinya mencakup pembuatan keputusan, akuntabilitas pelaksanaan kegiatan penggunaan TI, siapa yang mengambil keputusan, dan memanaje proses pembuatan dan pengimplementasian keputusankeputusan yang berkaitan dengan IT. Contoh bidang cakupan IT governance sektor publik adalah keputusan pemerintah yang menentukan siapa yang memiliki wewenang dan tanggungjawab dalam pembuatan keputusan tentang berapa jumlah investasi yang dapat dilakukan pada sektor publik $\mathrm{X}$ dengan memanfaatkan IT (Weill,2004).

Seperti yang tampak pada gambar 1 di bawah ini, proses IT Governance merupakan siklus proses yang dimulai dengan menentukan strategi, kebijakankebijakan IT, serta IT Objectives yang akan dicapai sampai tahap pengukuran pada performansi IT yang dihasilkan dan dibandingkan dengan IT Objectives yang telah ditetapkan sebelumnya.



Gambar 1. Proses IT Governance (De Haes, 2004)

\section{PT. Pertamina (Persero)}

PT. Pertamina memiliki bisnis proses yang terbagi menjadi 2, EksplorasiProduksi dan NonEksplorasi-Produksi. Pada bagian Eksplorasi-Produksi, kegiatan bisnis proses meliputi (1) Meningkatkan produksi dari lapangan eksisting, (2) Melakukan ekspansi kegiatan usaha dan operasi termasuk melalui cara anorganik (akuisisi), (3) Mengembangkan potensi CBM di wilayah Pertamina, (4) Melakukan aliansi strategis untuk ekspansi maupun membangun kemampuan spesifik.

Bisnis proses NonEksplorasiProduksi meliputi kegiatan - kegiatan (1) Meningkatkan bisnis perniagaan gas di dalam negeri serta memanfaatkan peluang untuk memperbesar bisnis transportasi dan pemrosesan gas melalui sinergisitas dengan AP Pertamina lainnya, (2)Pro aktif dalam perumusan pricing policy selaras dengan kebijakan nasional, (3)Peningkatan kapasitas dan kemampuan spesifik jasa 
pengeboran untuk menunjang rencana ekspansi perusahaan.

Sebagai salah satu perusahaan minyak terbesar di Indonesia, PT. Pertamina memiliki Visi dan Misi dalam menjalankan bisnis prosesnya. Visi dari PT. Pertamina adalah Menjadi Perusahaan Minyak Nasional Kelas Dunia. Untuk menunjang Visi tersebut, maka PT.Pertamina memiliki Misi, yaitu Menjalankan usaha inti minyak, gas dan bahan bakar nabati secara terintegrasi, berdasarkan prinsip-prinsip komersial yang kuat (Pertamina, 2010).

\section{Implementasi IT-Governance}

Sebelum melakukan implementasi IT pada PT. Pertamina, ada beberapa Kebijakan Umum yang diterapkan oleh PT.Pertamina. Kebijakan - kebijakan tersebut adalah

a. Teknologi informasi yang dibangun harus memiliki nilai yang sangat strategis dalam mendukung terciptanya produk atau jasa Perusahaan yang unggul dan kompetitif.

b. Investasi teknologi informasi harus mempertimbangkan aspek keuntungan berupa pengurangan biaya dan kemudahan memperoleh informasi.

c. Direksi menetapkan fungsi teknologi informasi yang :
1. bertanggung jawab untuk mewujudkan rancangan menjadi konstruksi yang detil

2. bertindak sebagai konsultan dengan melakukan komunikasi secara rutin dengan pihak pengguna (users)

3. memfasilitasi berlangsungnya pelatihan teknologi informasi

4. dibebaskan dari kegiatan pengadaan barang dan jasa yang berhubungan dengan kegiatan teknologi informasi

d. Fungsi teknologi informasi menerapkan mekanisme penjaminan mutu (Quality Assurance) untuk memastikan bahwa perangkat-perangkat dan sistem yang digunakan dalam teknologi informasi telah berada pada kualitas dan tingkat layanan yang diharapkan.

e. Fungsi pemakai (user) menerapkan penjaminan mutu (Quality Assurance) untuk memastikan bahwa data/informasi yang dihasilkan oleh sistem informasi telah berada pada kualitas, kuantitas dan waktu yang diharapkan.

f. Untuk memperoleh pemanfaatan yang aman dan optimal, fungsi teknologi informasi harus menerapkan kendalikendali terkait dengan aktivitas TI Implementasi Pengelolaan IT pada PT. Pertamina (Persero) dilakukan melalui beberapa tahapan dan proses. Tahapan tersebut adalah Tahap Pra-Implementasi, Tahap Implementasi dan Tahap Pengembangan. 
Pada tahap Pra-Implementasi, kegiatan-kegiatan yang dilakukan mencakup (1)Pencanangan visi dan misi di bidang teknologi informasi, (2) Penyusunan rencana strategis di bidang teknologi informasi yang sejalan (align) dengan strategi bisnis Perusahaan (3) Penyusunan rancangan dan desain teknis, dan (4) Penjabaran rancangan dan desain teknis teknologi informasi ke dalam konstruksi sistem secara fisik dan fungsional.

Setelah kegiatan praImplementasi dilakukan, maka tahap selanjutnya adalah tahap Implementasi. Kegiatan - kegiatan yang termasuk tahap Implementasi, yaitu (1) Perencanaan yang matang (2) Pelatihan dan pengembangan SDM

Pembakuan/standardisasi mutu layanan (4) Evaluasi dan pengendalian sistem (5) Penerapan sistem penanganan darurat (disaster recovery planning atau contingency planning).

Dan pada tahap Pengembangan, segala sesuatu yang berkaitan dengan Teknologi Informasi harus dilaksanakan dalam koridor penerapan teknologi informasi yang terintegrasi dan handal melalui (1) Penyusunan master plan pembangunan dan pengembangan teknologi informasi (2) Penerapan Executive Information System dan/atau Decision Support System (3) Penggunaan satu Enterprise Resources Planning (ERP) sebagai back office system, dan aplikasi ekstensi lainnya.

Pengendalian IT di PT. Pertamina menerapkan aturan-aturan sebagai berikut:

a. mempunyai prosedur dan indikator yang tepat untuk mengukur efektivitas pengelolaan TI.

b. mempunyai prosedur baku dalam menangani permasalahan teknologi informasi yang terjadi.

c. melakukan pemantauan secara berkala.

d. membuat laporan secara berkala kepada Direksi mengenai kinerja teknologi informasi

e. bersama-sama fungsi pemakai menetapkan tingkat layanan yang disepakati (service level agreement) dan direviu secara berkala.

\section{Kesimpulan}

IT memiliki peranan cukup penting dalam kemajuan dan dukungan terhadap bisnis proses sebua perusahaan atau organisasi. PT. Pertamina (Persero) sebagai perusahaan minyak dan gas terbesar di Indonesia juga menggunakan peran IT dalam mendukung bisnis proses yang dilakukannya.

Perhatian yang besar dari para pemimpin redaksi tentang peran IT dibuktikan dengan dilakukan pengawasan yang ketat terhadap sector-sektor IT yang dimiliki. Hal ini dilakukan perusahaan karena IT menyimpan seluruh data yang 
berkaitan dengan bisnis proses dan kelangsungan kegiatan perusahaan.

Selain dilakukan pengawasan, peran divisi IT pada perusahaan juga dilakukan pemeliharaan dan pengendalian yang cukup baik. Untuk setiap penggunaan, investasi hingga Sumber Daya Manusia yang berperan didalamnya, diatur sedemikian rupa sehingga Divisi IT pada PT.Pertamina tetap dipandang sebagai asset perusahaan.

\section{Daftar Pustaka}

Budiati , Ayuning., 2006, IT Governance Sektor Publik di Indonesia: Konsep dan Kebijakan, Prosiding Konferensi Nasional Teknologi Informasi \& Komunikasi untuk Indonesia, Bandung, pg. 57-61.

De Haes, Steven and Wim Van Grembergen. 2004. IT Governance and Its Mechanism, Information System Control Juornal Volume 1.ISACA

Hartanto, Indra Dwi dan Tjahyanto, Aries., 2008, Analisa Kesenjangan Tata Kelola Teknologi Informasi untuk Proses Pengelolaan Data Menggunakan COBIT (Studi Kasus Badan Pemeriksa Keuangan Republik Indonesia).
Mirbaha, Michael, 2008, IT Governance in Financial Services and Manufacturing Comparing the two sectors using COBIT 4.1 as framework, Stockholm, Sweden, XR-EE-ICS 2008:003

Sakam, R. Djunaedy dan Surendro Kridanto., 2005, Usulan Model Information Technology Governance Untuk Sistem Informasi Sumber Daya Manusia, Seminar Nasional Aplikasi Teknologi Informasi 2005, ISBN: 979-756061-6.

Surendro, Kridanto., 2008, Rancangan Tatakelola Teknologi Informasi untuk Pabrik Pupuk, Jurnal Informatika Vol. 9, NO. 2, pg. 115121.

Suryani, Arie Ardiyanti, 2009, Pengembangan Model Information Technology (IT) Governance pada Organisasi Pendidikan Tinggi Menggunakan COBIT 4.1 Domain PO DAN AI, Seminar Nasional Informatika, ISSN: 1979-2328.

Tata Kelola Perusahaan PT. Pertamina,2010.

Weill, P. and Ross, J.W., 2004, How Top Performers Manage IT Decision Rights for Superior Results, Harvard Business School Press, Boston. 